\title{
An approach for the generation of target product specifications in the development of home appliances
}

\author{
Marcel Morosini, Milton Borsato \\ Universidade Tecnológica Federal do Paraná - UTFPR \\ e-mails: marcel_morosini@hotmail.com; borsato@utfpr.edu.br
}

\begin{abstract}
Product designers need to conduct product development projects based on detailed and complete technical specs that mirror consumer requirements. Target product specifications poorly met or assumed incorrectly may potentially cause serious problems for companies such as excessive cost, low quality and long time-to-market. The main objective of the present work was to propose and validate an integrated solution (method and tool) for facilitating the generation of target specifications applicable to home appliance products. The proposed method is able to automatically generate target specifications for each sub-system of the product starting with customer needs as identified by Marketing teams. Information obtained in a systematic and assertive manner can then be used in the Conceptual Design stage of the product development process, when design solutions are generated. Results were validated through a comparative study of three products designed and manufactured by a large transnational home appliance manufacturer enterprise located in Brazil. Target specifications resulting from the application of the proposed tool were compared to actual characteristics of the products studied.
\end{abstract}

Keywords: home appliance; target specifications; product development.

\section{Introduction}

Surviving in the current fierce competitive market requires companies not only to develop new products which meet the needs of customers, but also to strive constantly for improving the quality perceived by the consumer, as well as reducing costs and development time (JIAO; CHEN, 2006). Therefore, it is necessary for designers to conduct product development projects based on detailed and complete technical specs that mirror the needs of consumers.

The process of determining target product specifications is critical and of utmost importance for launching products with high quality and low cost (NELLORE; SÖDERQUIST; ERIKSSON, 1999; ROZENFELD et al., 2006). Such specifications should consist of objectively described and structured data, clearly derived from the survey, analysis and understanding of customer needs, and deployed throughout the product development process. It is essential that this list of requirements be drafted properly for avoiding misinterpretations that would otherwise lead to mistaken conceptual alternatives.

Target product specifications poorly met or assumed incorrectly may potentially cause serious problems for companies such as excessive cost, low quality and long time-to-market. Without proper tools to produce product specifications, the qualified information withdrawn from the consumer market may be wasted, in the form of products that do not meet customer needs.

According to Cooper (2001), new products with clear and refined definition of target specifications have $85.4 \%$ chance of being successful, i.e. 3.3 times more than a product with poorly formulated specifications. Mckay, De Pennington and Baxter (2001) claim that target specifications are of better quality regarding completeness and consistency with the voice of the customer, when generated from methods and techniques specific to certain types of product. According to Baxter (1995), a few factors may determine the success or failure of a new product. In addition to aspects related to market orientation and internal factors to the company, prior planning of specifications increases by three times the odds of a product to be successful. For this, target specifications must be clearly defined before development is to be commenced.

Rozenfeld et al. (2006) and Cristiano, Liker and White (2000) suggest that QFD Quality Function Deployment is the most common method for converting the customer's voice into product specifications, mainly in the automotive industry. However, in other industries that require shorter time-to-market, such as the household appliance industry, methods for generating specifications are generally ignored. Slowness of existing methods, long time for completing 
tools and spreadsheets, and the need to bring together experts from different areas are the main obstacles for using QFD, which supposedly facilitate the development of product specifications (CHENG, 2002; JIAO; CHEN, 2006).

Household appliances are developed from target specifications that may not properly cover all the important features and aspects appointed by customers. This may create some problems in product development, such as delayed discussion of product specifications in the development process, frequent changes in specifications that impact time and cost of project, and excessively broad or overly strict requirements when there is no need.

Wei, Liu and Chen (2000) developed a system to automate the product development process. Through a software tool one can manage the product planning stages, survey of customer needs, product design to modeling virtual 3D prototypes. Product specifications are automatically generated by the software after the collection of customer needs. For Wei, Liu and Chen (2000), this system is able to structure and improve the conversion of customer needs in concrete product specifications and unambiguous and reduce changes throughout the project. Thus, the main benefits to the process of product development are: reduction of development time, reduction of costs and improvement of product quality. The system was developed for a shower nozzle, and further work should be undertaken to develop a generic system able to design different products. In this approach, a large number of geometric parameters for the automatic generation of 3D models from the specifications are required. This automated system has its application restricted to well-defined products. In this particular case, a shower nozzle was used, for which significant changes in the concept of the product are not intended.

$\mathrm{Yu}$, Wang and $\mathrm{Yu}$ (2008) proposed yet another method for generating target product specifications of customizable products using neural networks. In this case, the specifications are treated as variables in the process and represented by mathematical formulas. The neural network is a trained system capable of mapping customer needs into product specifications. This system is trained by iterative calculations based on existing case samples. In a layered architecture, the flow of information traverses the network in one direction, from input to output, ultimately resulting in product specifications. The first task is to discover customer needs and determine functional requirements with the application of QFD. Then, the neural network is used to define the specifications of other customers who want specific features in the product. The positive aspect of using neural networks is the ability to customize products through variable parameters. However, training neural networks involves complex mathematical calculations based on existing cases and probabilistic samples of training, which hinders its practical application.
The main objective of the present work was to propose and validate an integrated solution (method and tool) for facilitating the generation of target product specifications applicable to home appliance products. In order to concept proof this approach, a field study is carried out by means of comparing current product development practices and final features of a given product launched in the consumer market by a world-wide manufacturer of home appliances, to those virtually obtained with the use of the approach proposed by the present work.

The structure of the article contains a brief theoretical background on methods and tools for generating and managing specifications. The following section discusses methodological issues applied in the work, as well as the procedures for preparing and validating the proposed method. Following the results obtained from the field study, and, finally, the conclusions of this work are presented.

\section{Theoretical background}

The activity of developing product specifications is one of the most important ones in the beginning of the development phase because it brings together the entire set of attributes and goals that the product must meet (BACK et al., 2008). Therefore, it provides project information for subsequent development tasks. One of the most used and quoted tools in the literature for supporting the translation of customer requirements into product specifications is QFD.

QFD is a systematic way of obtaining information relating to quality, aiming to achieve the focus of quality assurance during product development (CHENG, 2007). According to Pahl et al. (2007), QFD aims to ensure product quality through product planning and the fulfillment of business processes oriented by costumer needs.

The use of QFD is simple. However, it is lengthy and time consuming because it is extensive and depends on many people from different departments. QFD also has certain subjectivity, since the result may vary depending on the participants. Some authors propose it to be adapted for overcoming such drawbacks. Lo, Tseng and Chu (2010) propose the application of QFD in only one step, with the aim of reducing the time and cost of development. The translation of the voice of the customer is conducted by specialists from different departments and occurs simultaneously to three houses of quality. Jiao and Chen (2006), on the other hand, propose that the processing requirements of consumers be divided into three steps: (i) explicitness for the requirements survey based on different types of customers and competitors' products; (ii) analysis for interpreting the voice of the customer; and (iii) specification for the precise definition of functional requirements.

Jiao and Tseng (1999) developed the PDFR method (Functional Requirements Product Database - Database for 
Product Functional Requirements), which is a systematic approach to draw up specifications by standards of functional requirements based on existing products. In this approach, the management of requirements is automated in the form of RMDB software (Requirement Management Database - Database for Requirements Management). The advantages of this method are related to the functions implemented by the software to integrate the requirements of consumers and product specification, generate product specifications that will meet customer needs and provide project information for those involved. Research techniques such as clinics, interviews and brainstorming are useful to highlight the voice of the customer, but it is difficult for Marketing to generate design requirements, as it does not have complete understanding of the information that Engineering needs for development. Through PDFR methodology, though, Marketing and Engineering teams share customer information in the same format and structured manner.

There are many other methods for mapping the voice of the customer into the voice of Engineering. Jiao and Chen (2006) comment on some of them, such as the optimization model and evaluation of the consumer (Core), a methodology for organizing specifications in Engineering (Moose), a kit of computational tools to generate specifications for products variants based on known standards requirements, and a redesign methodology based on the determination of specifications by projecting historical data. However, QFD is still recognized as the most used tool. The most discussed products in the literature regarding the specifications are related to the automotive, electronics and OEM products industry. Table 1 presents the main insights on the topic of product specification according to the type of product researched.

Table 1. Product specifications according to product type.

\begin{tabular}{|c|c|c|c|}
\hline Product Type & Perceptions & Product specifications & Source \\
\hline $\begin{array}{l}\text { Automotive } \\
\text { Aircrafts }\end{array}$ & $\begin{array}{l}\text { Marketing elaborates requirements in accordance } \\
\text { with customer needs and business strategies. } \\
\text { Engineering translates Marketing requirements } \\
\text { into Product specifications, involving other } \\
\text { areas such as Industrial Design, aftermarket and } \\
\text { suppliers. }\end{array}$ & $\begin{array}{l}\text { Technical specifications are generated in the } \\
\text { following order: } \\
\text { - general characteristics } \\
\text { - architecture } \\
\text { - subsystems } \\
\text { - components } \\
\text { In the aircraft industry, specifications are } \\
\text { managed through compliance cards. }\end{array}$ & $\begin{array}{l}\text { Nellore, } \\
\text { Söderquist and } \\
\text { Eriksson (1999) }\end{array}$ \\
\hline Automotive & $\begin{array}{l}\text { Product specifications have influence on the } \\
\text { decisions of development outsourcing to } \\
\text { suppliers. }\end{array}$ & $\begin{array}{l}\text { Elaboration of a matrix to assist the decision } \\
\text { indicates type of supplier necessary, product, } \\
\text { generator, nature of specification, evaluation } \\
\text { of degree of competitiveness and strategic } \\
\text { vulnerability. }\end{array}$ & $\begin{array}{l}\text { Nellore and } \\
\text { Söderquist (2000) }\end{array}$ \\
\hline $\begin{array}{l}\text { "Black Box" } \\
\text { Products }\end{array}$ & $\begin{array}{l}\text { Work plan based on a number of factors } \\
\text { involving the relationship with suppliers to assist } \\
\text { the development, management and evaluation of } \\
\text { product specifications. } \\
\text { Modifications on specification throughout } \\
\text { development are inevitable, and must be } \\
\text { interpreted as a competitive advantage, and not } \\
\text { wasted time. }\end{array}$ & $\begin{array}{l}\text { The main specification problems regarding } \\
\text { suppliers are of technical content, modifications, } \\
\text { cost, interpretation and supplier involvement in } \\
\text { the process. } \\
\text { Specifications in "black box" are considered } \\
\text { adjustable technical documents. }\end{array}$ & $\begin{array}{l}\text { Karlsson, Nellore } \\
\text { and Soderquist } \\
(1998)\end{array}$ \\
\hline Electronics & $\begin{array}{l}\text { A good management system specification } \\
\text { product in the customer-supplier collaborative } \\
\text { environment is crucial to the development of } \\
\text { quality products. }\end{array}$ & $\begin{array}{l}\text { The main specification management problems } \\
\text { between company and suppliers are frequent } \\
\text { changes, too general or too rigid specifications, } \\
\text { standardization and optimization of insufficient } \\
\text { cost. } \\
\text { Practices for better management performance } \\
\text { suggested specifications should be implemented } \\
\text { in practice. }\end{array}$ & $\begin{array}{l}\text { Lam, Chin and } \\
\text { Cheung (2006) }\end{array}$ \\
\hline Bus & $\begin{array}{l}\text { Different types of customers; entrepreneur and } \\
\text { end-user buyer must be studied for surveying the } \\
\text { needs of the consumer. }\end{array}$ & $\begin{array}{l}\text { Product specifications are generated from } \\
\text { information from internal sources (strategic } \\
\text { planning, business objectives, history of previous } \\
\text { development) and external (customer survey). }\end{array}$ & $\begin{array}{l}\text { Lamb and } \\
\text { Tamagna (2010) }\end{array}$ \\
\hline $\begin{array}{l}\text { Sustainable } \\
\text { Products }\end{array}$ & $\begin{array}{l}\text { Need to include environmental, social and } \\
\text { economic aspects in the design specifications. }\end{array}$ & $\begin{array}{l}\text { Construction of a systematic requirements } \\
\text { management appropriate to the sustainable PDP } \\
\text { to facilitate the development of sustainable } \\
\text { solutions effectively. }\end{array}$ & $\begin{array}{l}\text { Marx and Paula } \\
(2011)\end{array}$ \\
\hline
\end{tabular}

Source: the authors. 


\section{Methodological aspects}

A case study was adopted as the research strategy for this work. A field research was conducted in a large transnational home appliance manufacturer enterprise located in Brazil. The research was carried out through individual interviews with open-ended questions using a semi-structured questionnaire, which allows a greater depth in the approach when necessary.

Interviews were conducted with 20 key people in the company, who take part in the planning stage of the project and informational design. The interviewees are managers and project leaders from the departments of Marketing, Industrial Design and Engineering, responsible for different product lines.

The requirements for the proposed method were then identified. Thus, alternatives for a tool were generated for subsequent evaluation. The deliverable for this step was a tool prototype, which presented the best potential to meet the proposed requirements.

\subsection{Creation of method and tool}

The architecture of the tool is similar to the neural network proposed by Yu, Wang and Yu (2008). It consists of three layers: (i) an input layer that brings data of customer needs; (ii) a hidden layer for processing and crosschecking with the database; and (iii) an output layer composed of target product specifications.

The list of specifications is formalized to the entire project team, and serves as a reference for the development of solutions in the next step of generating solutions for the product. Figure 1 shows the functional model for the proposed method based on the PDFR method. Project information from Marketing should be forwarded to Engineering, which automatically generates target product specifications through a tool based on the concept of an expert system. The list of specifications is formalized to the entire project team, and serves as reference for the development of solutions in the next stage of development, Conceptual Design.

The database tool is created based on previous product development projects and tacit knowledge captured from experts. Thus, it is possible to generate specifications based on requirements, features, metrics and pre-established values. For organizing the database, it is necessary to consider the product structure, in systems and subsystems. The database is comprised of all known customer requirements for each subsystem. Such requirements are directly related to specifications of known products.

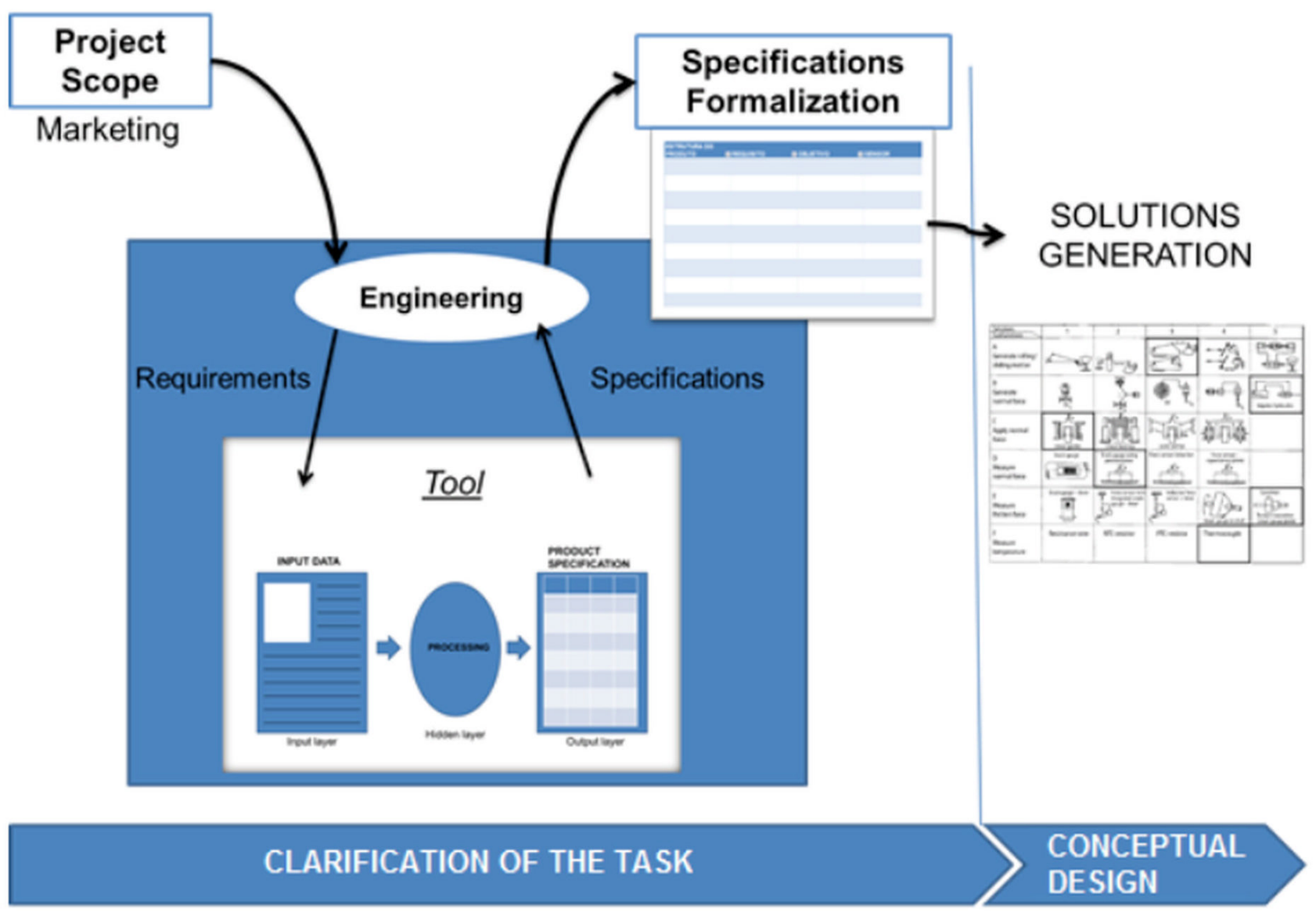

Figure 1. Functional model of the proposed method. Source: the authors. 
The correlation structure of the product, which links customer requirements to target specifications, is performed using an operation flow as shown in Figure 2. This overall system is deployed as a combination of subsystems that meet certain requirements. Therefore, the more complex a given subsystem is, the greater the amount of scrolling levels and requirements is. Thus, for each different combination of requirements, there is a set of target specifications for meeting the initial Marketing demand for a product.

In order to test and validate the method, three real cases were selected for tool implementation and verification. The case studies were conducted in the context of projects that had already been finished in accordance with current corporate procedures. The proposed tool and method would be validated if results from its implementation were equal to or better than those found on existing product specifications.

\section{Results and discussion}

The main perceptions identified in interviews with employees involved in the product development process in the company studied were investigated. A list of requirements that a method and tool should have to be really useful in daily business was obtained. The main requirements raised were: (i) ability to formalize target specifications in a single document, containing objective and clear data; (ii) ease of handling; (iii) ability to increase assertiveness in a project; (iv) accessibility for the sake of constant specifications checking; and (v) no dependence on designer experience.

Based on these requirements, an analysis of existing methods for the generation of target specifications of a cooker was carried out. For that, current practices adopted for product development process within the studied company were considered, as well as input information from Marketing.

Input data are transmitted primarily through briefing and design reviews. This information is then forwarded to Engineering, which would automatically generate target specifications using an expert-system-like tool.

For the construction of the expert system prototype, a cooker was selected as a test case. The product breakdown structure was realized as presented in Figure 3, based on knowledge and experience of the Engineering staff. Then the main requirements and corresponding target specifications for each product subsystem were defined.

Regular spreadsheets were used as a primary means for deploying the system. Thus, three worksheets were created: (i) input data for selecting requirements for each subsystem;
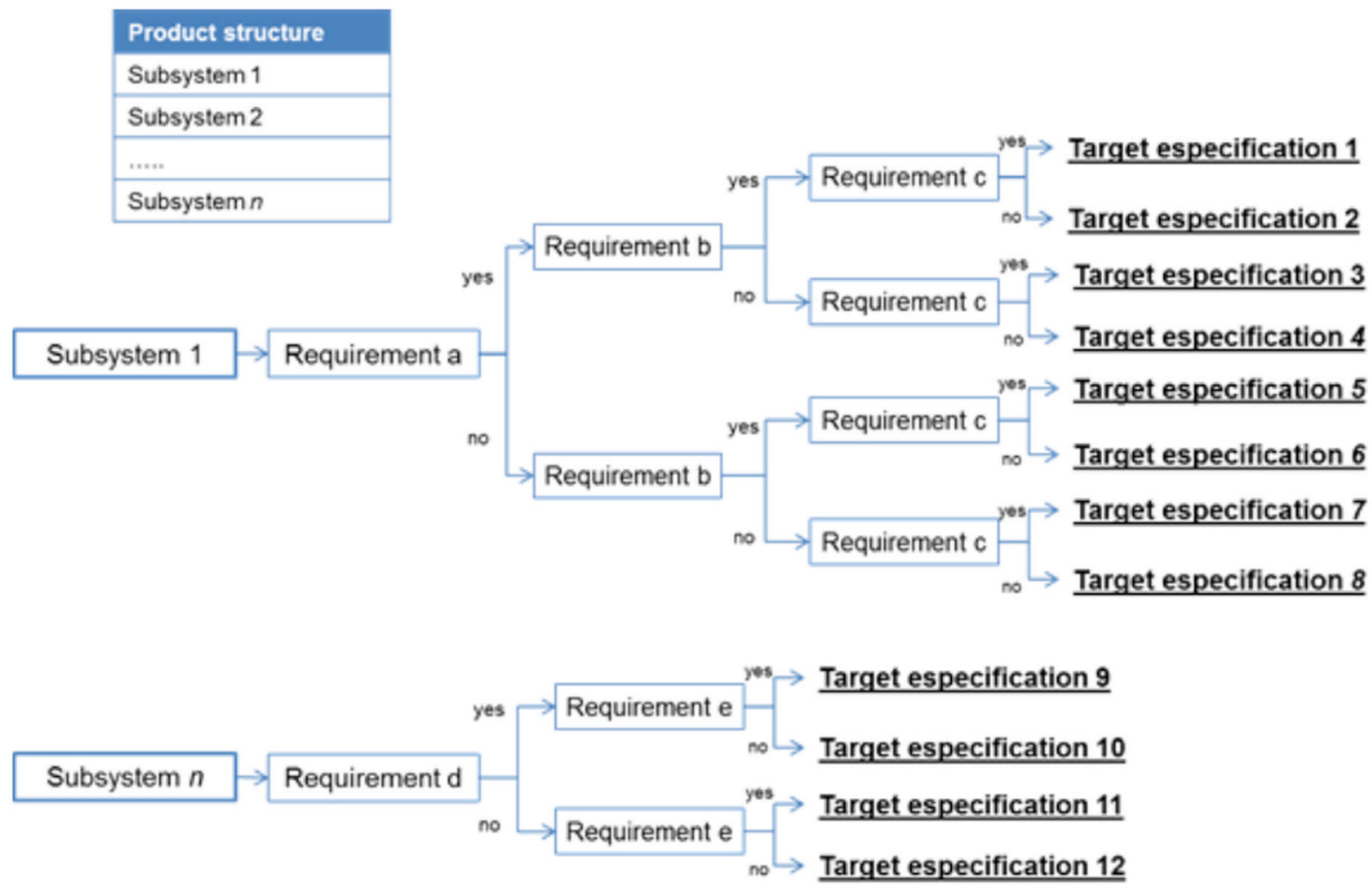

Figure 2. Operation flow. Source: the authors. 


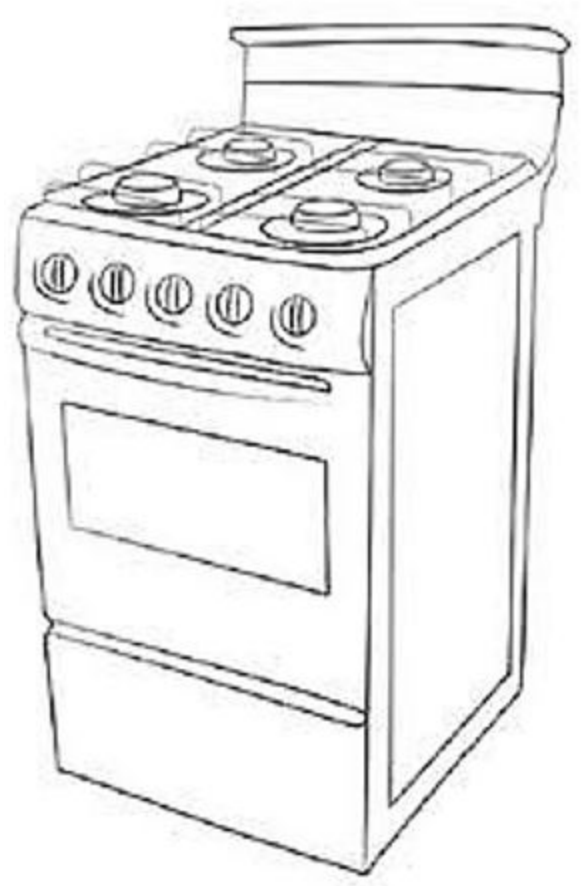

Figure 3. Product breakdown structure. Source: the authors.

(ii) processing for capturing input data and exchanging information to and from the database; and (iii) product specifications, which presents the resulting list of target specifications in the form of tables.

The selection of requirements in the input data spreadsheet was performed using combination boxes containing, in most cases, options "yes" or "no" (Figure 41). In some cases, the options of the check box were more specific, e.g. the number of burners that the stove must have. The worksheet cells are protected against modifications; therefore, one can only select the options offered in the combinations boxes and enter the value of the final price of the product at a retail store.

The processing worksheet detects the input data, correlates these requirements with the database, and automatically checks which target specification option meets the desired feature. This check is done automatically through the chain of operations prepared.

The requirement selection in the combinations boxes of the input data spreadsheet returns a numeric value for the processing worksheet. This resulting value is 1 if the "yes" is selected, and 2 for the "no" option. According to the possible combinations of requirements, the corresponding number combinations in the database are identified. Then the resulting values of the combo boxes are confronted by conditional formulas with the database. Therefore, the set of customer requirements is determined, as well as the corresponding target-specification.

\footnotetext{
${ }^{1}$ In Figures 4, 5, 6, 7 and 8 consider comma as decimal separator.
}
- Price*
- Knobs
- Oven
- Platform
- Electrical/electronic system
- Gas - insulation system (big oven)
- Hob
- Cover
- Gas - insulation system (small oven)
- Grill pan support
- Handle
- Ignition
- Burners
- Door
- Color
- Hob efficiency*
- Stove
- Security NBR 13723-1*
*Non-physical project drivers

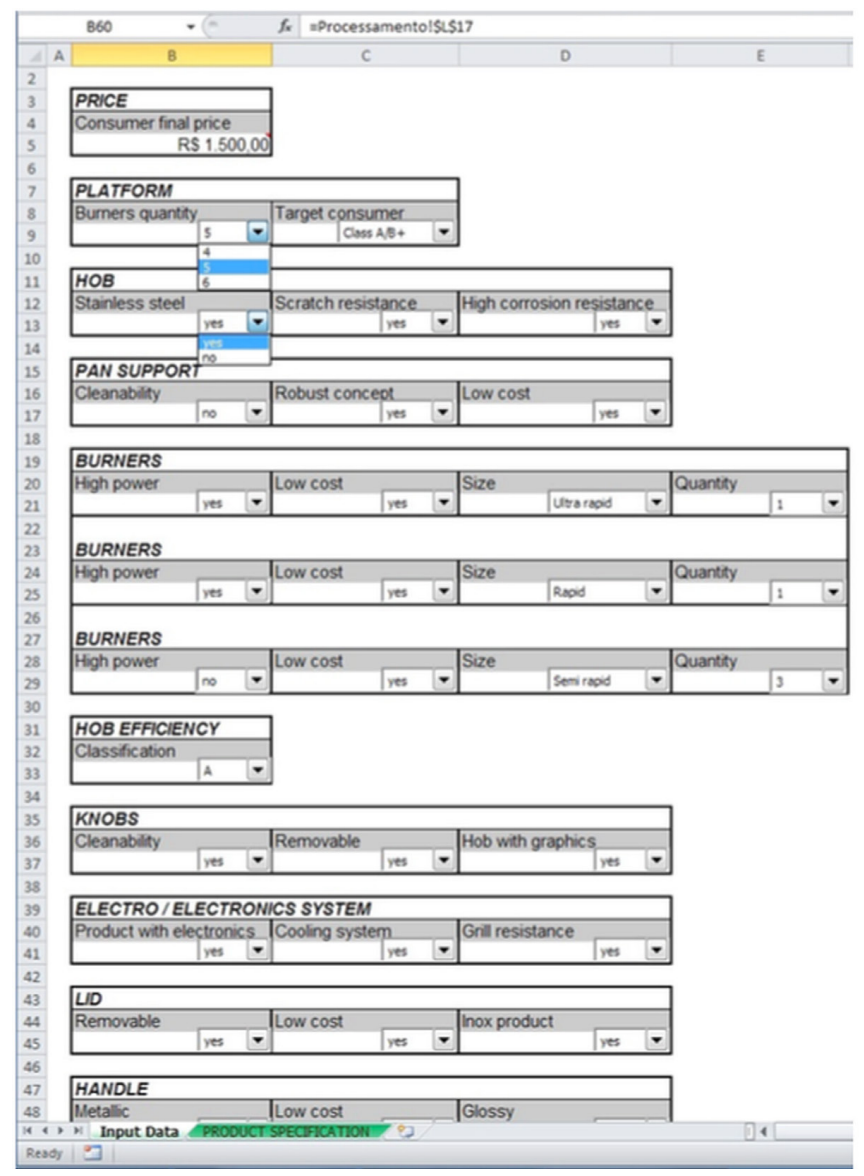

Figure 4. Input data spreadsheet. Source: the authors. 
Figure 5 shows the processing spreadsheet, with emphasis on the previous example of the pan support grid. Columns $\mathrm{C}$, $\mathrm{E}, \mathrm{G}$ and I present the numeric outcome from the selection of combo boxes. Column J lists the possible numerical combinations, or combination of requirements, which the subsystem can meet. Columns $\mathrm{K}$ and L show customer requirements and target specifications for each numeric combination.

For the end user and in real conditions of tool use, this worksheet should be hidden and protected from modification.
This is to preserve the logic implemented on the basis of conditional formulas for determining the specifications. A user with administrator permissions can easily perform tool maintenance, involving database updates with new information and technologies developed.

The result of processing can be seen in the product specification sheet generated by the tool (Figure 6). In this table, the subsystems are characterized with their customer requirements, technical and measurable objectives of targetspecifications, and which means are needed for verifying

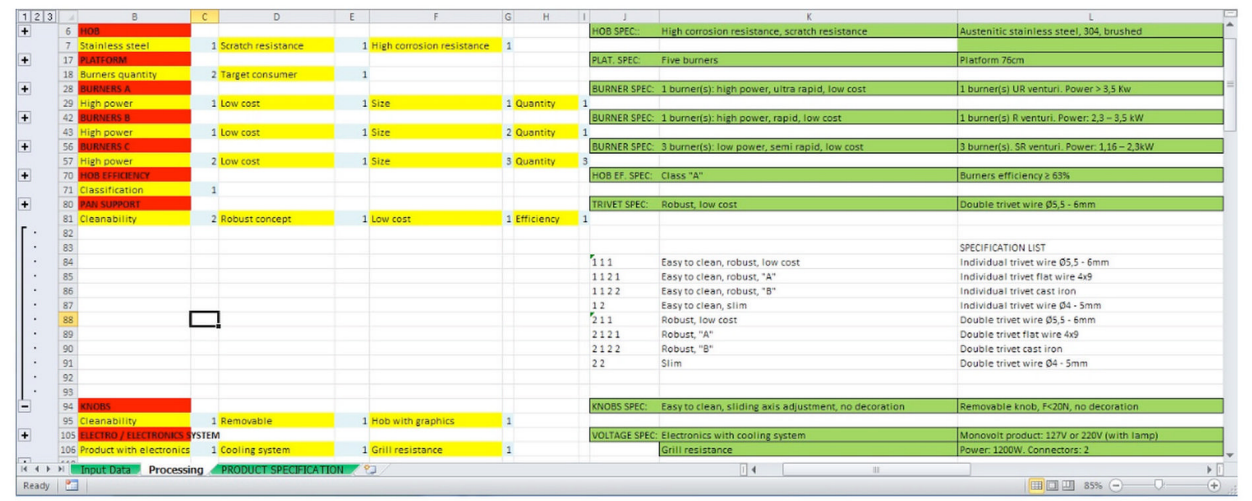

Figure 5. Processing spreadsheet. Source: the authors.

\begin{tabular}{|c|c|c|c|c|}
\hline $1 /$ & A & B & c & D \\
\hline 1 & Product Breakdown Structure & Requirement & Target & Sensor \\
\hline 2 & & Consumer final price $=$ RS 1500 & Raw material cost $<$ RS500 & calculator \\
\hline$\frac{2}{3}$ & $\frac{\text { PRIE }}{\text { PLATFORM }}$ & $\begin{array}{l}\text { Consumertinal price }=R S 1500 \\
\text { Five burners }\end{array}$ & $\begin{array}{l}\text { RaW matelial cost }<\text { Rs500 } \\
\text { Plattorm } 76 \mathrm{~cm}\end{array}$ & $\begin{array}{l}\text { Cacularor } \\
\text { visual/measure tape }\end{array}$ \\
\hline 4 & HOB & High corrosion resistance, scratch resistance & Austenitic stainless steel, 304, brushed & microscopenisual \\
\hline$\frac{3}{6}$ & PAN SUPPORT & Robust, low cost & Double trivet wire $₫ 5,5$ - $6 \mathrm{~mm}$ & visual/caliper rule \\
\hline 7 & BURNERS & 1 burner(s): high power, ultra rapid, low cost & 1 burner(s) UR venturi. Power $>3.5 \mathrm{Kw}$ & tests \\
\hline 8 & & 1 burner(s): high power, rapid, low cost & 1 burner(s) R venturi. Power: $2,3-3,5 \mathrm{~kW}$ & tests \\
\hline 9 & & 3 burner(s): low power, semi rapid, low cost & 3 burner(s). SR venturi. Power. $1,16-2,3 \mathrm{~kW}$ & tests \\
\hline 10 & HOB EFFICIENCY & 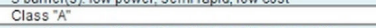 & Burners efficiency $=63 \%$ & tests \\
\hline 11 & KNOBS & Easy to clean, sliding axis adjustment, no decoration & Removable knob, $F<20 \mathrm{~N}$, no decoration & dynamometer/visual \\
\hline 12 & ELECTRO / ELECTRONICS SYST & ElElectronics with cooling system & Monovolt product $127 \mathrm{~V}$ or $220 \mathrm{~V}$ (with lamp) & tests, visual \\
\hline 13 & & Grill resistance & Power: $1200 \mathrm{~W}$. Connectors: 2 & tests \\
\hline 14 & UID & Removable & Balanced hinge & visual \\
\hline 15 & & Low cost & Flat glass lid & visual $/ \mathrm{mmc}$ \\
\hline $\begin{array}{l}15 \\
16\end{array}$ & HANDLE & $\begin{array}{l}\text { Low cost } \\
\text { Metalic, low cost. glossy }\end{array}$ & $\begin{array}{l}\text { Har guass lid } \\
\text { Tubular steel painted handle }\end{array}$ & $\begin{array}{l}\text { Usual/fmic } \\
\text { microscopenisual }\end{array}$ \\
\hline 17 & $D O O R$ & Good visiblility, good looking. modem & Door with external curved glass & visual $/ \mathrm{mmc}$ \\
\hline 18 & & Easy to clean & Removable inner glass & visual \\
\hline 19 & & Low cost & Inner door of enameled steel plate & microscopenisual \\
\hline 20 & STOVE & No stove & & visual \\
\hline 21 & OVEN & Plattorm 76, biggest category oven & Volume $>119,5 \mathrm{~L}$ & measure tape \\
\hline 22 & & $\begin{array}{l}\text { Easy to clean } \\
\text {. }\end{array}$ & easy clean" enameling & \\
\hline 23 & & Efficiency $A^{*}$ & Maintenance consumption $\leq 49 \%$ & 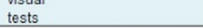 \\
\hline 24 & $\begin{array}{l}\text { GAS - INSULATION BIG OVEN } \\
\text { SYSTEM }\end{array}$ & Plattorm 76, product with electronics and cooling system & $\begin{array}{l}\text { Oven gas tap: } \min \text { flow } 44 \mathrm{~lm} \\
\text { Oven injector } 0.86\end{array}$ & $\begin{array}{l}\text { tests } \\
\text { profile projector }\end{array}$ \\
\hline 26 & 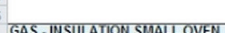 & & Oven insulation: glas fiber, thick $40 \mathrm{~mm}$, dens. $20 \mathrm{~kg} / \mathrm{m} 3$ & measure tape / weighing scale \\
\hline$\frac{27}{28}$ & $\begin{array}{l}\text { GAS. INSULATION SMALL OVEN } \\
\text { SYSTEM }\end{array}$ & Double oven product with electronics, small gas oven & $\begin{array}{l}\text { Oven gas tap: } \min \text { flow } 18 \mathrm{~lm} \\
\text { Oven injector. } 0,59\end{array}$ & $\begin{array}{l}\text { tests } \\
\text { profile projector }\end{array}$ \\
\hline $\begin{array}{l}29 \\
30 \\
31\end{array}$ & IGMIIION & Automatic ignition & $\begin{array}{l}\text { Oven insulation: glass fiber, thick } 40 \mathrm{~mm} \text {, dens. } 20 \mathrm{~kg} / \mathrm{m} 3 \\
\text { gnition time }<55\end{array}$ & $\begin{array}{l}\text { measure tape / weighing scale } \\
\text { chonometer }\end{array}$ \\
\hline $\begin{array}{l}31 \\
32 \\
33 \\
34 \\
35\end{array}$ & COLOR & White product & $\begin{array}{l}\text { Ginition button on the panel } \\
\text { Color B07875: side panels, feet, stove } \\
\text { Color B00097: door glass } \\
\text { Color B00099: lid glass }\end{array}$ & $\begin{array}{l}\text { Visual } \\
\text { color standard } \\
\text { color standard } \\
\text { color standard }\end{array}$ \\
\hline 36 & SAFETY NBR 13723.1 & Heating & Door. $\triangle 80^{\circ}$ & thermocouple \\
\hline 37 & & & Handle: $\Delta 35^{\circ}$ & thermocouple \\
\hline 38 & & & knob: $\triangle 60^{\circ}$ & thermocouple \\
\hline 39 & & & Lid. $\Delta 45^{*}$ & thermocouple \\
\hline 40 & & & Hoo panel: $\triangle 60^{\circ}$ & thermocouple \\
\hline 41 & & & Electronic components: $80^{\circ} \max$ & thermocouple \\
\hline 42 & & Mechanical resistance & $F$ horizontal $=500 \mathrm{~N}$ & dynamometer \\
\hline 43 & & & No displacement among parts & visual \\
\hline 44 & & Shelves resistance & mass $=11,6 \mathrm{~kg}$ & weighing sacle \\
\hline 45 & & & inclination $<10^{\circ}$ & goniometer \\
\hline 46 & & Door resistance & mass $=10 \mathrm{~kg}$ & weighing sacle \\
\hline 47 & & & displacement $<15 \mathrm{~mm}$ & measure tape \\
\hline 48 & & Tumbling & mass in the door center $=22,5 \mathrm{~kg}$ & weighing sacle \\
\hline 49 & & & not tumbling & visual \\
\hline 50 & & Tightness & gas system leakage < 0,10dm3/h@15kPa & tightness equipment \\
\hline 52 & & & $\begin{array}{l}\text { torque }>0,2 \mathrm{Nm} \\
\text { cydes }=40000\end{array}$ & torquimeter \\
\hline 53 & & Combust & $\mathrm{CO}<0.15 \%$ & tests \\
\hline 54 & & Overfon & no flam & visual \\
\hline 55 & & Airflow & no flar & visual \\
\hline 56 & & Tightness / maintenance & gas system leakage <0.10dm3/h@15kPa & tightness equipment \\
\hline 57. & & & quantity of disassembling / assembling & counter \\
\hline
\end{tabular}

Figure 6. Target specifications. Source: the authors. 
the targets. Again, this worksheet is also protected against modification of any content, since it contains formulas related to the processing worksheet; its only use is for presentation of results.

To validate the proposed method, a comparative study was conducted, based on three products that have already been developed by the company in the past. The objective was to compare target specifications resulting from the application of the proposed tool to the actual characteristics of the product.

Therefore, validation began with the collection of project information used at the time of development of a particular stove in Company X. Company employees helped provide the information for the validation tool. Figure 7 shows the application tool in this study.

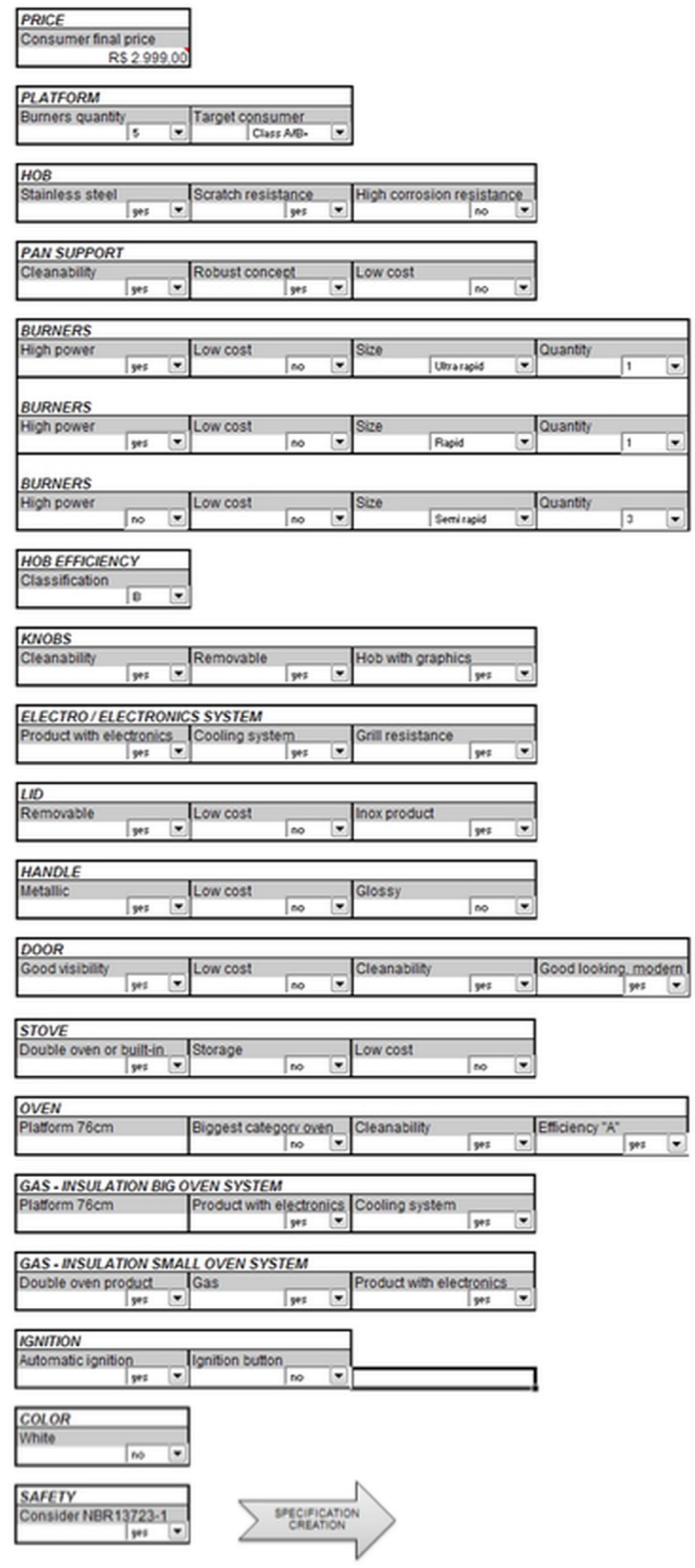

Figure 7. Input data for tool validation. Source: the authors. 


\begin{tabular}{|c|c|c|c|c|}
\hline Product Breakdown Structure & Requirement & Target & Sensor & Specification OK? \\
\hline PRICE & Consumer final price $=\mathrm{R} \$ 2999$ & Raw material cost $<$ R $\$ 999,67$ & calculator & ok \\
\hline PLATFORM & Five burners & Plattorm $76 \mathrm{~cm}$ & visual/measure tape & OK \\
\hline \multirow{2}{*}{ HOB } & Low cost stainless steel, scratch resistance & Ferritic stainless steel, 439 , brushed & microscopehisual & ok \\
\hline & & & & OK \\
\hline PAN SUPPORT & Easy to clean robust "B" & Individual trivet cast iron & visual / caliper rule & $\mathrm{OK}$ \\
\hline \multirow[t]{3}{*}{ BURNERS } & 1 bumer(s): high power, ultra rapid & 1 UR burner(s) sealed. Power $>3.5 \mathrm{KW}$ & tests & OK \\
\hline & 1 burner(s): high power, rapid & $1 \mathrm{R}$ burner(s) sealed Power: $2,3-3,5 \mathrm{~kW}$ & tests & ok \\
\hline & 3 burner(s): low power semi rapid & 3SR burner(s) sealed. Power: $1,16-2,3 \mathrm{~kW}$ & tests & ok \\
\hline HOB EFFICIENCY & Class " 8 " & Burners efficiency. $61-63 \%$ & tests & ok \\
\hline KNOBS & Easy to clean. slidino axis adjustment, no decoration & Removable knob. $F=20 \mathrm{~N}$, no decoration & dynamometer/visual & OK \\
\hline \multirow[t]{2}{*}{ ELECTRO / ELECTRONICS SYSTE } & IElectronics with cooling system & Monovolt product $127 \mathrm{~V}$ or $220 \mathrm{~V}$ (with lamp) & tests, visual & ok \\
\hline & Grill resistance & Power: 1200 W. Cannectors: 2 & tests & ok \\
\hline \multirow[t]{2}{*}{ LID } & Removable & Balanced hinge & visual & ok \\
\hline & Stainless steel product & Mirrored "stop sol" curved glass & usual $/ \mathrm{mmc}$ & ok \\
\hline HANDLE & Metallic, cost is secondary, matt & Extruded anodized aliminium brushed handle & microscopehisual & ok \\
\hline \multirow[t]{3}{*}{ DOOR } & Good visibility, good looking, modern & Door with external curved glass & visual / mmc & ok \\
\hline & Cost is secondary & Plastic inner door PA6 $30 \%$ glass fiber Tmáx $=220^{\circ} \mathrm{C}$ & visual/themocouple & ok \\
\hline & Easy to clean (plastic inner door) & Removable inner glass & microscopensual & ok \\
\hline STOVE & No stove & - & visual & ok \\
\hline \multirow[t]{3}{*}{ OVENI } & Plattorm 76 . not the biggest category oven & Volume $=93.2 \mathrm{~L}$ & measure tape & ok \\
\hline & Easy to clean & "easy clean" enameling & visual & ok \\
\hline & Etiliency $A^{-}$ & Maintenance consumption $=49 \%$ & tests & OK \\
\hline \multicolumn{5}{|l|}{ GAS - INSULATION BIG OVEN } \\
\hline \multirow[t]{3}{*}{ SYSTEM } & Platiorm 76, product with electronics and cooling system & Oven gas tap: $\min$ flow $44 \mathrm{l} / \mathrm{h}$ & tests & ok \\
\hline & & Oven injector. 0.86 & profile projector & ok \\
\hline & & Oven insulation: glas fiber, thick. $40 \mathrm{~mm}$, dens. $20 \mathrm{~kg} / \mathrm{m} 3$ & measure tape / weighing scale & ok \\
\hline \multirow{4}{*}{$\begin{array}{l}\text { GAS - INSULATION SMALL OVEN } \\
\text { SYSTEM }\end{array}$} & & & & \\
\hline & Double oven product with electronics, small gas oven & Oven gas tap: $\min$ flow $18 \mathrm{l} / \mathrm{h}$ & tests & OK \\
\hline & & Oven injector: 0,59 & profile projector & ok \\
\hline & & Oven insulation: glass fiber, thick $40 \mathrm{~mm}$, dens. $20 \mathrm{~kg} / \mathrm{m} 3$ & measure tape / weighing scale & ok \\
\hline \multirow[t]{2}{*}{ IGIITION } & Super automatic ignition & Ignition time $\times 5 \mathrm{~s}$ & chonometer & ok \\
\hline & & Switch attacheo to the gas tap & visual & OK \\
\hline \multirow[t]{4}{*}{$\overline{\text { COLOR }}$} & Stainless steel product & Color B02044: side panels, complement panel, stove & color standard & ok \\
\hline & & Color 800261 : teet & color standard & ok \\
\hline & & Color 800094 : door glass & color standard & ok \\
\hline & & Color B10002: lid glass & color standard & OK \\
\hline \multirow{22}{*}{ SAFETY NBR 13723.1 } & Heating & Door: $\triangle 80^{\circ}$ & thermocouple & ok \\
\hline & & Handle: $\Delta 35^{\circ}$ & thermocouple & OK \\
\hline & & $k n \circ b: \triangle 60^{\circ}$ & thermocouple & ok \\
\hline & & Lid: $\triangle 45^{\circ}$ & thermocouple & ok \\
\hline & & Hob panel: $\triangle 60^{\circ}$ & thermocouple & ok \\
\hline & & Electronic components: $80^{\circ}$ max & thermocouple & ok \\
\hline & Mechanical resistance & $\mathrm{F}$ horizontal $=500 \mathrm{~N}$ & dynamometer & ok \\
\hline & & No displacement among parts & visual & ok \\
\hline & Shelves resistance & mass $=9.5 \mathrm{~kg}$ & weighing sade & ok \\
\hline & & indination $<10^{\circ}$ & goniometer & ok \\
\hline & Door resistance & mass $=10 \mathrm{~kg}$ & weighing sacle & ok \\
\hline & & displacement $<15 \mathrm{~mm}$ & measure tape & $\mathrm{OK}$ \\
\hline & Tumbling & mass in the door center $=22,5 \mathrm{~kg}$ & weighing sacle & ok \\
\hline & & not tumbling & visual & OK \\
\hline & Tightness & gas system leakage < 0,10dm $3 / \mathrm{h} @ 15 \mathrm{kPa}$ & tightness equipment & ok \\
\hline & Gas tap demobilization/mobilization & torque $>0.2 \mathrm{Nm}$ & torquimeter & OK \\
\hline & & cycles $=40000$ & counter & ok \\
\hline & Combustion & $\mathrm{co}<0.15 \%$ & tests & OK \\
\hline & Overflow resistance & no flame extinguish by water overflow & visual & ok \\
\hline & Aiffow resistance & no name extinguish by airflow & visual & OK \\
\hline & Tightness / maintenance & gas system leakage < $0.10 \mathrm{dm} 3 \mathrm{~h} @ 15 \mathrm{kPa}$ & tightness equipment & ok \\
\hline & & quantity of disassembling / assembling & counter & ok \\
\hline
\end{tabular}

Figure 8. Processing spreadsheet. Source: the authors.

After processing the information, the tool generates the meta-specifications for the product in question as shown in Figure 8. It was found that the specifications automatically generated by the tool when fed by data available during the project development are in accordance with the developed product, therefore validating the designed system.

Target specifications were confirmed by observation of physical characteristics of the product and results of laboratory tests. Tool validation was made from the point of view of quality, because the method application generates a set of target specifications, which corresponds to the actual product the way it has been implemented.

The tool is not able to identify aspects such as cost and time gains with its implementation. As the tool is based on data from past products, it could only be applied in the process development of well-known products, with no new technologies involved.

\section{Conclusion}

A method and an expert-system-like tool were designed to outline the generation of target specifications of house appliances. A cooker was selected as a case study. The proposed method is able to automatically generate target specifications for each sub-system of the cooker starting with customer needs as identified by Marketing teams. Information obtained in a systematic and assertive manner can then be used in the Conceptual Design stage of the PDP, when design solutions are generated.

A database was built based on the history of previous developments and tacit knowledge of experts. The proposed method is applicable in cases of incremental change projects on known products. However, this method is not applicable for innovative projects with new technologies, since there is 
no historical data to be used as a starting step for generating target specifications.

The developed method allows that customer requirements are met. The method provides the following features: (i) ease of use; (ii) grouping and formalization of target specifications in a single document; (iii) insensitiveness to external interference; and (iv) addressing of design assertiveness. Another attribute of the proposed method is the reduction of subjectivity in generating target specifications of appliances.

The proposed approach fills a gap in the literature regarding the generation of target specifications in the home appliance industry. As QFD is not widely used in this industrial sector, no other peculiar method has been identified to assist in generating specifications due to particularities of this segment. Therefore, the proposed method provides the possibility to reduce time and project cost and guarantee quality of the final product due to reduced redesign and rework.

\section{References}

BACK, N. et al. Projeto integrado de produtos. Planejamento, concepção e modelagem. Barueri: Manole, 2008.

BAXTER, M. Product Design: practical methods for the systematic development of new products: London: Chapman \& Hall, 1995.

CHENG, L. C. A Guide for QFD Implementation in Product Development. Product: Management \& Development, v. 1, n. 3, p. 5-15, 2002.

CHENG, L. C. QFD: desdobramento da função qualidade na gestão de desenvolvimento de produtos. Blücher, 2007

COOPER, R. G. Winning at new products: accelerating the process from idea to launch. Basic Books, 2001

CRISTIANO, J. J.; LIKER, J. K.; WHITE, C. C. CustomerDriven product development through quality function deployment in the US and Japan. Journal of Product Innovation Management, v. 17, n. 4, p. 286-308, 2000.

JIAO, J.; TSENG, M. M. A requirement management database system for product definition. Integrated Manufacturing Systems, v. 10, n. 3, p. 146-154, 1999.

JIAO, J. R.; CHEN, C.-H. Customer requirement management in product development: a review of research issues. Concurrent Engineering, v. 14, n. 3, p. 173-185, 2006.
KARLSSON, C.; NELLORE, R.; SODERQUIST, K. Black box engineering: redefining the role of product specifications. Journal of Product Innovation Management, v. 15, n. 6, p. 534-549, 1998.

LAM, P.-K.; CHIN, K.-S.; CHEUNG, W.-Y. Product specification management in collaborative NPD: an investigation of problems and good practices in Electronics Industry. Asian Journal on Quality, v. 7, n. 1, p. 35-47, 2006.

LAMB, M. B.; TAMAGNA, A. Study of the product development process and attributes of a touring coach project: a case study). Design \& Tecnologia, n. 1, 2010. (in Portuguese).

LO, C.-H.; TSENG, K. C.; CHU, C.-H. One-Step QFD based 3D morphological charts for concept generation of product variant design. Expert Systems with Applications, v. 37, n. 11, p. 7351-7363, 2010.

MARX, A. M.; PAULA, I. C. D. Proposal of systematic requirements management for sustainable product development process. Revista Produção, v. 21, n. 3, p. 417-431, 2011.

MCKAY, A.; DE PENNINGTON, A.; BAXTER, J. Requirements management: a representation scheme for product specifications. Computer Aided Design, v. 33, n. 7, p. 511-520, 2001.

NELLORE, R.; SÖDERQUIST, K.; ERIKSSON, K.-Å. A specification model for product development. European Management Journal, v. 17, n. 1, p. 50-63, 1999.

NELLORE, R.; SÖDERQUIST, K. Strategic outsourcing through specifications. Omega, v. 28, n. 5, p. 525-540, 2000.

PAHL, G. et al. Engineering design: a systematic approach: Springer, 2007. v. 157.

ROZENFELD, H. et al. Product Development Management: a reference for process improvement. São Paulo: Saraiva, 2006. 19 p. (in Portuguese).

WEI, C.-C.; LIU, P.-H.; CHEN, C.-B. An automated system for product specification and design. Assembly Automation, v. 20, n. 3, p. 225-233, 2000.

YU, L.; WANG, L.; YU, J. Identification of product definition patterns in mass customization using a learning-based hybrid approach. International Journal of Advanced Manufacturing Technology, v. 38, n. 11-12, p. 1061-1074, 2008. 